\section{BIBLIOTECA \\ JORGE D. WLLIAMS}

Joturnal of Herpetology, Vol. 16, No. 4, pp. 354-363, 1982

Copyright 1982 Society for the Study of Amphibians and Reptiles
COLECCION HERPETOLOGIC

Y BIBLIOTECA

Dr. José Miguel Cei

\title{
A New Species of the Patagonian Genus Vilcunia, with Remarks on Its Morphology, Ecology and Distribution
}

\author{
José M. Cei ${ }^{1}$ ANd José A. SCOlaro \\ Departamento de Ciencias Naturales, Universidad Nacional de Rio Cuarto, \\ Cordoba Province, Argentina, and Centro Nacional Patagónico, \\ Puerto Madryn, Chubut Province, Argentina
}

\begin{abstract}
A new species of the genus Vilcunia from near Lago Belgrano, $47^{\circ} 50^{\prime}$ South latitude, Santa Cruz, Argentina, is described. The morphology of the new species, $V$. periglacialis sp. nov. and the closely related $V$. silvanao are compared and a redescription of $V$. silvanae is made. Both species are of biogeographical interest given their distribution in the basaltic mesetas of the slopes of the Patagonian Andes.
\end{abstract}

The genus Vilcunia was established for a peculiar tropidurine lizard collected by one of us while exploring the isolated volcanic plateau of the meseta of Lago Buenos Aires, in the province of Santa Cruz, southern Argentina. The original description (Domoso and Cei, 1971) of the unique species, Vilcunia silvanae, was very brief; however, some of the most distinctive features of this unusual generic taxon were pointed out. Phyletic and morphological relationships with both Liolaemus and Proctotretus were also suggested. However, Etheridge (in Paull, Williams and Hall, 1976) inferred from its description that Vilcunia is allied to the Liolaemus-Phymaturus-Ctenoblepharis complex and not to Proctotretus. The recent discovery (December 1980) of a new species of $\mathrm{Vil}$ cunia from the basaltic landscape close to the Belgrano and Burmeister lakes, Santa Cruz (from $47^{\circ} 40^{\prime}$ to $48^{\circ}$ South latitude) underscores the herpetological, and biogeographical interest of this poorly known southern Patagonian genus. The Belgrano and Burmeister glacial lakes extend on the eastern slopes of Patagonian cordilleras, about $150 \mathrm{~km}$ south of the meseta of Lago

Present address: Rancho Somuncurá, Rua Fausto de Figueiredo, Birre, 2750, Cascais, Portugal.
Buenos Aires. They lie in the ecotonal zone between the eastern borders of the cold Chilean Nothofagus forest and the dry Patagonian steppe, and are included within the protected natural landscape of the National Park Perito Moreno, whose zoological communities are as yet very poorly explored (Fig. 1). The new species of Vilcunia is described below, together with a systematic reconsideration of the closely related Vilcunia silvanae. A more detailed comparative examination of morphological and biogeographical features of these uncommon Patagonian iguanids is given in the ecological remarks and discussion.

Specimens cited are in the Museo Zoologico of the University of Florence, Italy (MZUF); Instituto M. Lillo, Tucumán, Argentina (FML); Museo de la Plata, Argentina (MLP); Museo Argentino Ciencias Naturales, Buenos Aires (MACN); Colección Herpetologica-Centro Nacional Patagónico, Puerto Madryn, Argentina (CH-CNP); Museum of Natural History, University of Kansas (KU); Museum of Comparative Zoology, Harvard University (MCZ); Museum National d'Histoire Naturelle, Paris (MNHNP); Museu de Zoologia da Universidade de Sảo Paulo, Brasil (MZUSP); Instituto Butantán, São Paulo, Brasil (IB); and in the J. M. CeiDiagnostic Collection (JMC-DC). 


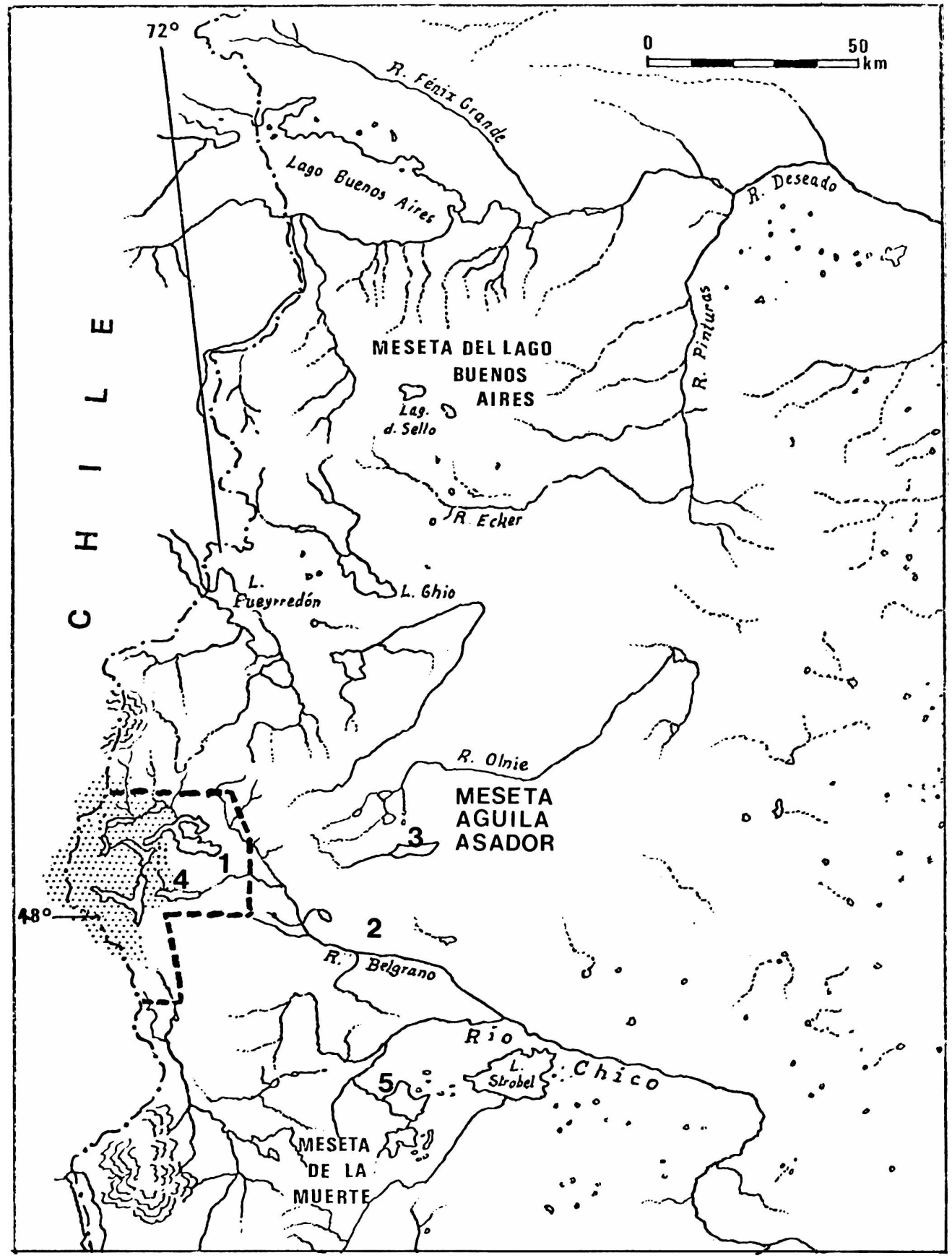

FIC. 1. The Patagonian basaltic mesetas near $8^{\circ} \mathrm{S}$ latitude, in the Argentine Patagonia, Santa Cruz Province. The Perito Moreno National Park $(115,000 \mathrm{ha})$ is outlined by a broken line. The stippled area represents the easternmost distribution of the Nothofagus forest. The numbered localities are: 1 . Estancia Lago Belgrano, type locality of Vilcunia periglacialis; 2. Estancia Cerro Beltza on the southern slope of the Meseta Aguila Asador; 3. Lago Guitarra; 4. Lago Burmeister; 5. Lago Quiroga. 

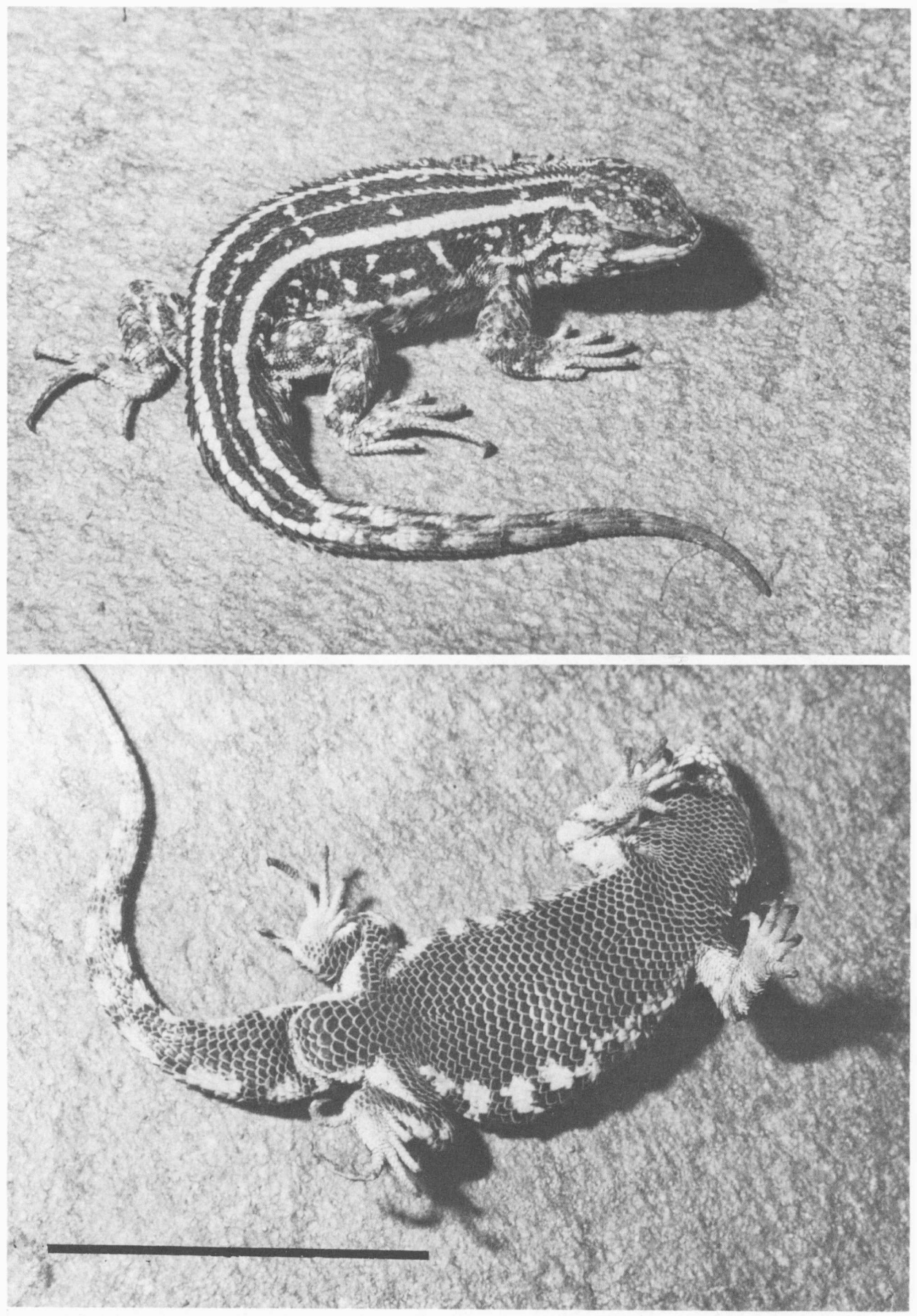

FIG. 2. Holotype of Vilcunia periglacialis, a male from the neighborhood of Lago Belgrano. Scale indicates $5 \mathrm{~cm}$. 
Vilcunia periglacialis sp. nov.

(Fig. 2)

Holotype.-MZUF 26939, male from a ravine $6 \mathrm{~km}$ east Estancia Lago Belgrano, 1000 m, Santa Cruz, Argentina, 8 December 1980, J. M. Cei and J. A. Scolaro, Collectors.

Paratypes. -MZUF 26940-26944 (2 os $\delta$, $3 \%$ q), MACN 31500-31503 (2 \& $\delta, 2$ $q q)$ and JMC-DC 506-512 (5 $\delta \delta, 2$ $q$ \&), all same data as holotype; JMC-DC

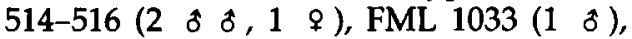
MCZ 161084-161088 (2 of $\delta, 3$ \% \%), northern borders of Rio Belgrano, 950-970 m, 2 February 1981; JMC-DC 520-525 (3 $\delta$ ช , 3 \& \&), near Lake Guitarra on meseta Aguila-Asador, 30 January 1981; FML 1032 (1 \&) ), JMC-DC 517-519 (1 \& , 2 \& \&), MLP 697-700 (2 o $\delta, 2$ imm.), CH-CNP 121, 131-134 (4 of $\delta, 1$ \&), Cerro Beltza, $10 \mathrm{~km}$ east Lago Belgrano, $1000 \mathrm{~m}, 29 \mathrm{Jan}-$ uary 1981; CH-CNP 135-136, 138, 145 (3 o o , 1 \&), FML 1034-1036 (1 \&, 2 imm.), Meseta Aguila-Asador, near Lake Guitarra, $1300 \mathrm{~m}$, 30 January 1981; MZUSP $57275-57280$ (3 o $\delta, 3$ ㅇ \&), IB 5125 (1 क), KU 190410-190414 (3 \& \&, 2 ㅇ \&), MNHNP 1981. 500-504 (2 of of, 2 \& $\&, 1$ imm.), sandy steppe near Lake Guitarra, Meseta Aguila-Asador. 30 January 1981; MCZ 161082-161083 (2 of of ), JMC-DC 513 (1 $\delta$ ), ravines near Estancia Lago Belgrano, $110 \mathrm{~m}, 2$ February 1981; MCZ 161089 (1 \%), ravines near Estancia Cerro Beltza, $1000 \mathrm{~m}, 12 \mathrm{~km}$ east Lago Belgrano, 29 January 1981. All in the province of Santa Cruz. Collections in 1981 were made by J. A. Scolaro and J. Upton.

Diagnosis. - Vilcunia periglacialis may be distinguished from the only other species in the genus, $V$. silvanae, by its more slender aspect and smaller size, larger head, shorter hind limbs, distinctly trifid dorsal scales, less evident lateral and nuchal tufts, a distinct antehumeral pocket, a smaller number of scales around the middle body, and a very different coloration (Fig. 3).

Description of Holotype.-Body slender, tail shorter than snout-vent length. Head length more than one fifth body length; head longer than wide, length contained in 11 dorsal scales. Longitudinal and transverse antehumeral folds very distinct, with enlarged, bristled, smooth scales, arranged as lateral tufts; an antehumeral pocket. Snout gently rounded; rostral more than twice as wide as high; nasal separated from rostral by two small scales. Nostrils smaller than nasal scale, opening laterally, nearer tip of snout than eye. Ear opening large, oval, edged by four enlarged or conical scales anteriorly, by small, bristled scales posteriorly. Temporal scales bulky, weakly keeled, irregular in size. Scales of frontal, parietal and occipital region slightly bulky and rugose, rather regularly arranged; an azygous frontal. Interparietal scale almost equal to parietals. Three large supraoculars, separated from superciliaries by two or three rows of small, irregular scales. Subocular large, undivided; a single series of scales with numerous scale organs between labials and subocular; 6 supralabials, 5 infralabials. Mental subtriangular. Eyelid unfringed. Scales on neck strongly keeled and bristled, conical or trifid. Scales across gular region between tympani 24-26. Scales of axillary region granular. Dorsal scales imbricate, strongly keeled, mucronate and bristled, trifid with lateral mucrones. No median dorsal scale row; dorsals smaller than ventrals; narrower in dorsal rows, wider in dorso-lateral region. Lateral scales smooth, as larger as dorsolaterals; ventrals imbricate, subtriangular and smooth, smaller in gular region. No gular fold; a moderate longitudinal fold on sides of body. Dorsal caudal scales strongly keeled, mucronate, similar to dorsals at the base of tail, squarish elsewhere; lateral mucrones indistinguishable. Ventral caudal scales subtriangular and smooth, weakly keeled on tip of tail. Number of scales around middle body 48 ; subdigital lamellae of fourth finger 14-15; of fourth toe 18 .

Dorsal scales of forelimb large, smooth or weakly keeled; posteriorly smaller, keeled and mucronate, ventrally smooth and rounded, strongly imbricate, tricarinate on plantar surface of the hand. 

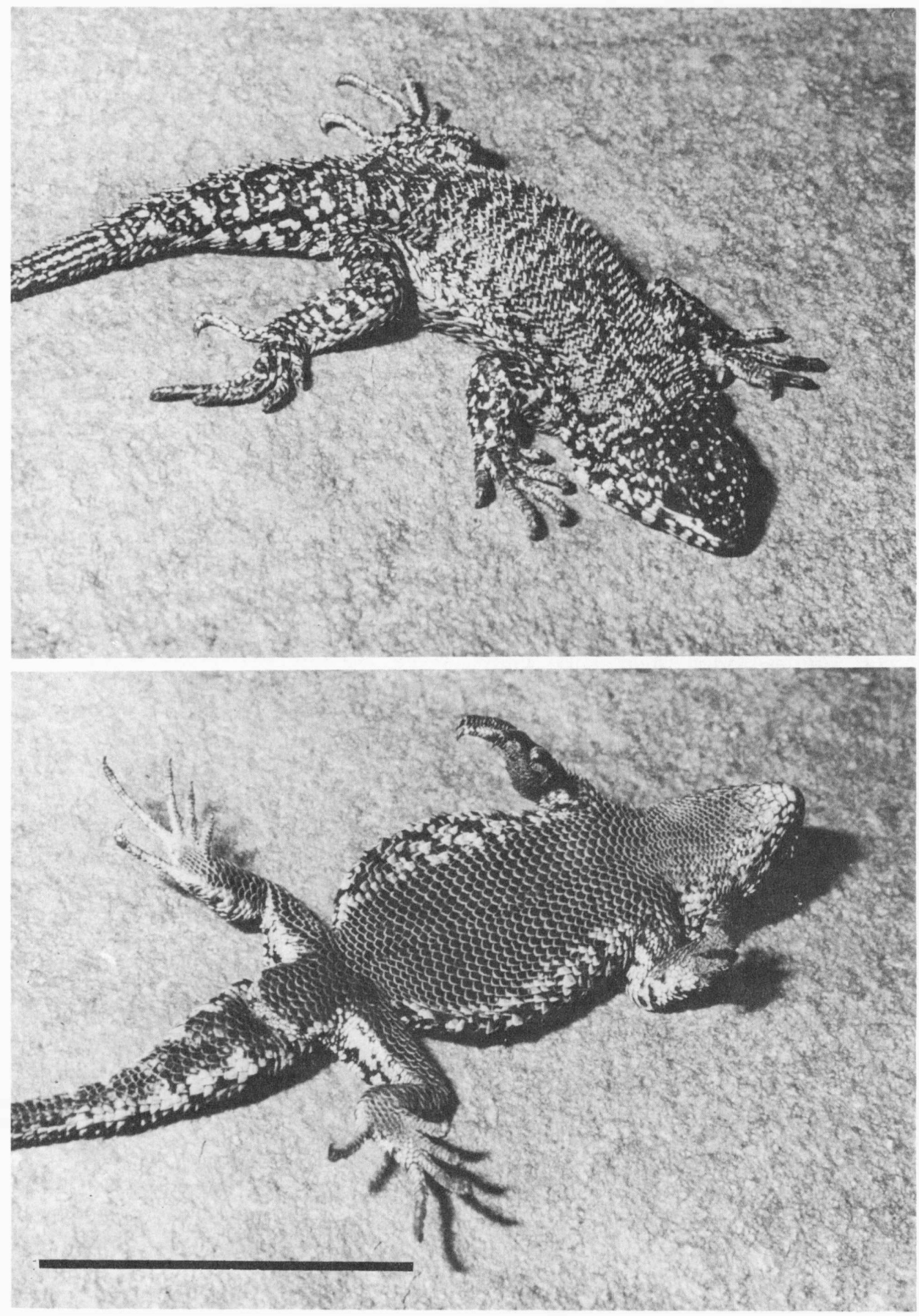

FIG. 3. Male of Vilcunia silvanae from the meseta south of Lago Buenos Aires. Scale indicates $5 \mathrm{~cm}$. 
Supradigital scales large and smooth, subdigitals tricarinate. Dorsal scales of thigh and tibia acuminate, strongly keeled, imbricate; ventral scales large and smooth, imbricate; enlarged scales on outer tibial region and posterior ventral borders of thighs. Small conical scales on thigh posteriorly. No preanal pores. Hind limb short, not reaching axillary region when adpressed. Fourth finger of adpressed forelimb reaching middle of body.

Measurements of holotype ( $\mathrm{mm})$ : total length 108, snout-vent 58.5, head length 12 , head width 11 , forelimb 19 , hind limb 29 , axilla-groin 27.5 .

Dorsum black, with two longitudinal white stripes as wide as a dorsolateral scale, extending from supraocular region to middle of tail; a very faint narrow bluish vertebral line. Whitish irregular spots on dorsum, flanks and limbs; a broken white spotted line on lateral fold, with alternate black and white marks below. Ventrally black, with whitish scales on mental region and ventral surface of forelimbs. Transverse dorsal and ventral dark and white bands on tail. Thighs whitish posteriorly.

Variation.-A total of 43 males and 36 females were captured and observed. Female specimens are slender and smaller than males. Snout-vent length in $\mathrm{mm}$ ranges from 53 to $73\left(\bar{x}_{33}=61.90\right)$ in adult males, from 54 to $70\left(\bar{x}_{20}=58.40\right)$ in adult females. Hind limbs of females are shorter than those of males, not reaching axilla when adpressed: axilla-groin/hind limb ratios range from 88 to 104 in males, from 93 to 120 in females. White lateral stripes and ventral melanism are often faint or absent in females; antehumeral tufts are somewhat larger in males. As in $V$. silvanae, size and shape of the cloacal region are the most distinctive morphological sex differences. Transverse cloacal diameter is swollen and larger than longitudinal diameter in males, flattened and equal to longitudinal diameter in females; the base of tail is conspicuously dilated in adult males. No sexual differences exist in subdigital lamellae of fourth finger (15-18) and fourth toe (17-21), in number of scales in middle of body (45-56), or in number of scales in which head length is contained (10-13).

Distribution.-From Lake Belgrano and Rio Belgrano to mesetas Pampa del AguilaPampa del Asador and Lake Guitarra, about $70 \mathrm{~km}$ eastward, Province of Santa Cruz, Argentina.

Etymology. - The name refers to the geographic distribution of the species, near the inland glaciers of Patagonia.

Remarks. - Vilcunia periglacialis lives under scattered stones or gravel in the steppe, and in the basaltic ravines of the mesetas. Ecologically it is a more versatile form than $V$. silvanae, being found on the borders of the wet Nothofagus forest neighboring Lake Belgrano $(1000 \mathrm{~m})$, as well as in the sandy semidesertic environments surrounding Lake Guitarra, on the dry Aguila-Asador volcanic highlands $(1300-1400 \mathrm{~m})$. Like $V$. silvanae, it is primarily an herbivorous lizard, feeding on buds and flowers of composites but also feeding on arthropods. However, $V$. periglacialis showed a lesser proportion of plant remains than $V$. silvanae which have approximately $90 \%$ of the stomach contents composed of plants.

In $46 \%$ of 74 observed specimens of $V$. periglacilais, and in $51 \%$ of $37 \mathrm{~V}$. silvanae broken or regenerated tails were found.

Histological examination of the testes of $V$. periglacialis indicates that the males reach sexual maturity at $52 \mathrm{~mm}$ SVL. The smallest female with well developed oocytes had a SVL of $52 \mathrm{~mm}$. In $V$. silvanae males mature at $65 \mathrm{~mm}$ and females at 66 mm SVL.

Both species are viviparous and pregnant females of both species have been found in December. In $V$. periglacialis birth probably occurs in February since females had 2-4 almost completed developed embryos in the oviducts in February 1981. Females of $V$. silvanae have given birth in February.

The region inhabited by $V$. periglacialis has a temperate cold, humid climate. Its environment is characterized by the 
abundance of hemicryptophytic plants, such as Viola, Leucheria, Plantago, Geranium, Phacelia, Calceolaria, Armeria, Bellis, Erigeron, Gamochaeta, Anemone, Saxifraga, Poa, and Festuca. Mesophanerophytes and nanophanerophytic shrubs are also present in the ecotonal zone, such as the Nothofagus antarctica clusters, Berberis buxifolia, B. empetrifolia, B. heterophylla, or rosulate and/or pulvinate chamaephytes as Acaena, Nardophyllum, Cerastium, Colobanthus and Mulinum. The winter season is very snowy and cold; temperatures of about $3^{\circ} \mathrm{C}$ with a relative humidity of about $38 \%$ were registered in the early morning during our summer stay in the neighborhood of Lago Belgrano (December 1980). In the area where Vilcunia periglacialis was initially collected, near the Belgrano and Burmeister lakes, some minor faunal elements are anyphaenid and thomisid spiders (Petricus sp.), scorpions (Urophonius granulatus), heteroptera, wingless orthopterans, tipulid dipterans, hymenopterans (wasps of the genus Hypodynerus; ants such as Camponotus distinguendus) and coleopterans such as the abundant coprophagous beetles Taurocerastes patagonicus. Aquatic biotopes in the ecotonal zone are characterized by the austral fish Galaxias platei, a minute clam (Pisidium patagonicum), amphipods as Hyalella curvispina, and dytiscid beetles as Lancetes varius.

Due to the brief original description of the Vilcunia generotype (1971) a redescription of Vilcunia silvanae follows, for a more suitable evaluation of this species group and its taxonomic significance.

Redescription of Vilcunia silvanae.-Body stout and flattened, tail shorter than snout-vent length. Head length less than one fifth body length: head as long as wide, length contained in 11-15 dorsal scales. Swollen longitudinal and transverse antehumeral folds, or tufts, without distinct antehumeral pocket. Scales on tufts very acuminate, conical and bristled. Snout gently rounded, rostral slightly more than twice as wide as high; nasal in contact with rostral or separated by two small scales. Nostrils smaller than nasal scale, opening laterally, equidistant from tip of snout and the anterior corner of the eye. Ear opening large, oval, almost hidden by lateral nuchal tufts, edged by several conical scales anteriorly, by minute conical or bristled scales posteriorly. Temporal scales bulky, distinctly keeled, regularly arranged. Scales of frontal, parietal and occipital region large and bulky, regularly arranged and smooth; an azygous frontal. Interparietal scale smaller than or equal to parietals. Supraoculars large, 5-4 separated from five enlarged superciliaries by two-three rows of very irregular smaller scales. Subocular large, undivided; a single scale row between labials and subocular; 6-5 supralabials, 5 infralabials. Mental subtriangular. Eyelid unfringed. Scales on neck small, strongly keeled and bristled. Scales across gular region between tympani 26-28. Scales of the axillary region small, smooth, rounded or notched. No median dorsal scale row; dorsal scales imbricate, strongly keeled and bristly, heterogeneous, smaller on vertebral line and trifid, with lateral mucrones. Dorsals slightly smaller than ventrals. Lateral scales very weakly keeled, larger than dorsals and laterodorsals. Ventrals imbricate, subtriangular, smooth, smaller in gular region. No distinct gular fold; a longitudinal fold on sides of body. Dorsal caudal scales strongly keeled, imbricate, similar to dorsals at the base of tail, squarish elsewhere. Ventral caudal scales smooth, rounded or subtriangular, weakly keeled on tip of tail. Number of scales around middle of body 55-68; subdigital lamellae of fourth finger 17-20, of fourth toe 19-23.

Dorsal scales of forelimb large, weakly keeled, smaller posteriorly, ventrally rounded and smooth, keeled on plantar surface of the hand. Supradigital scales smooth; infradigital lamellae tricarinate. Dorsal scales of thigh and tibia large, strongly keeled, imbricate; ventrals large and smooth, imbricate; plantar scales of foot small, keeled; enlarged scales on outer tibial region and posterior ventral borders of thigh. Small, conical scales on posterior thigh. No preanal pores present. Hind limb reaching axillary region when 
adpressed; fourth finger of adpressed forelimb reaching the middle of body. Size (in $\mathrm{mm}$ ): snout-vent length 65.5 to 77 in 16 adult males, 66 to 77 in 14 adult females (means: 72.62 in males, 70.79 in femalesa significant difference from $V$. periglacialis, at a $P<0.001$ ).

Dorsum black with symmetrical dorsolateral or lateral areas of blue, yellow and white marks and point, frequently intensely blue or yellow. Ventrally bluish black, with brilliant blue lateral markings. Bluish or whitish spots on tail. Blue colors are generally maintained in alcohol preserved specimens. Vilcunia silvanae is only known from its terra typica, the basaltic plateau of the meseta of Lago Buenos Aires.

\section{DisCUSSION}

The discovery of Vilcunia periglacialis south of the range of $V$. silvanae, in the volcanic highlands on the boundary of the Santa Cruz Cordilleras, adds considerable interest to this distinctive iguanid genus. In addition it provides us with the opportunity to compare its external morphology and lepidosis with those of other iguanid genera, especially the genus Liolaemus to which it is almost certainly most closely allied.

The primary character separating Vilcunia from Liolaemus is the evidence of dorsal scales showing lateral mucrones, or "trifid" scales (Fig. 4). No species of the highly diversified genus Liolaemus exhibit such unusual scales, having only rounded and/or pointed, smooth and/or keeled, often unimucronate, dorsal scales. Trifid dorsals also appear to be unique in the South American tropidurine lineage such as formerly recognized by Etheridge (1964). No examined iguanid species of the genera Tropidurus, Platynotus, Phymaturus, Stenocercus, Proctotretus, Ctenoblepharis, Plica, Uracentron, Uranoscodon, Strobilurus, Leiocephalus, possess true trifid scales or developed nibs. A number of other iguanid genera were examined and also found ot lack these trifid scales: Leiosaurus, Aperopristis, Diplolaemus, Pristidactylus, Urostrophus, Polychrus, Anolis, Eny-
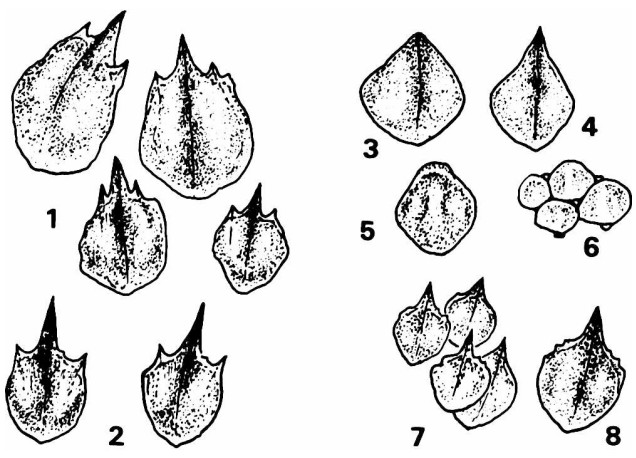

FIG. 4. Trifid, keeled dorsal scales of Vilcunia: 1. V.periglacialis, 2. V. silvanae. Keeled or smooth dorsal scales of some species of Liolaemus: 3. L.kingi; 4. L. cyanogaster; 5. L.jamesi; 6. smooth, juxtaposed scales of $L$. anomalus. Keeled, dorsal scales of: 7 . Liolaemus lineomaculatus and 8. Proctotretus pectinatus; slightly acuminate and/or dentate lateral expansions or mucrones are often present.

alius, Enyalioides, Anisolepis, Aptycholaemus, Hoplocercus. Scales hardly approximate to those of Vilcunia by shape, slightly notched edge and keels, were observed either in specimens of Liolaemus lineomaculatus from Santa Cruz (Fig. 4), and in some tropidurine species as Proctotretus pectinatus, Stenocercus guenteri, and Tropidurus torquatus; however, the characteristic trifid Vilcunia scales were never found. We believe that a character such as this is so peculiar as to warrant the retention of Vilcunia as separate genus. However, Vilcunia appears to be closely related to Liolaemus on the basis of many other aspects of lepidosis and body morphology: such as head scalation, body, limbs and tail shape, the absence of a complete transverse gular fold and lack of a medial dorsal scale row.

Besides Vilcunia, lateral bristly folds or tufts are not known in any species of Liolaemus, or in most tropidurine genera, with some exceptions as Plica, Tropidurus, Platynotus, Stenocercus, Strobilurus and Phymaturus. General features and the scalation of tufts are remarkably different in all of the above mentioned lizards. Individual variation exists, being greater in Vilcunia periglacialis than in $V$. silvanae. Moreover, interspecific differences are 
shared by all of these genera, considering that, i.e., lateral bristly folds in Vilcunia periglacialis, Plica umbra or Tropidurus torquatus, do not develop as in Vilcunia silvanae, Plica plica or Tropidurus bogerti. Questions pertaining to the evolutionary or adaptive value of those differences remain unanswered.

The posterior thigh scales are granular in Liolaemus, but moderate, acuminate and/or conical in Vilcunia. They are small, smooth imbricate, subimbricate or scarcely juxtaposed in $V$. periglacialis, larger, faintly keeled or notched in $V$. silvanae. The posterior surface of thighs is granular in many, mostly tropidurine, iguanid lizards, such as Phymaturus, Polychrus, Anisolepis, Anolis auratus, Leiosaurus, Aperopristis, Diplolaemus, Pristidactylus, Urostrophus and Hoplocercus. Small spiny and/or weakly keeled scales were observed in Proctotretus, Plica, Tropidurus, Platynotus, Strobilurus, Uranoscodon, Enyalius, Enyalioides and Leiocephalus. This minor trait of the scalation provides yet another argument for the recognition of Vilcunia and Liolaemus as separated genera. Finally the absence of preanal pores is another major difference between Vilcunia and Liolaemus. Preanal pores in males (both in male and female in few species, although reduced in the latter), appear to be quite constant in Liolaemus, except only in L. lineomaculatus from Santa Cruz, in which preanal pores are absent. That was carefully checked by us in adults from Puerto Deseado, Santa Cruz, terra typica of $L$. lineomaculatus Boulenger, as well as others from the eastern slopes of the meseta of Lago Buenos Aires, sympatric with $V$. silvanae. Our finding contrasts with Donoso's statement (1966) that eight yellowish preanal pores are present in adult males from Magellanic regions. Whether or not the lack of preanal pores will prove to be a constant specific character of $L$. lineomaculatus must await examination of many more individuals. However, the problem is suggestive enough to warrant wider investigation. We notice that $L$. lineomaculatus appear to be the only Liolaemus species having scattered dorsal scales roughly resembling the characteristic trifid Vilcunia scales.

Although an extensive cytogenetic research on phyletic groups of Liolaemus is being carried out at present (Veloso, pers. comm.), conclusive data on karyotype evolution are still unavailable. Data on 24 species seems to suggest a generalized pattern of $2 n=12+(18$ to 28$)$. The $12+24$ pattern was indicated as primitive in iguanids (Paull, Williams and Hall, 1976). At a first approach Vilcunia seems to resemble Liolaemus karyologically. In Vilcunia silvanae 12 macrochromosomes and 20 microchromosomes are found (Veloso, pers. comm., in press). In $V$. periglacialis 12 meta-submetacentric macrochromosomes, 2 small acrocentric macrochromosomes and 18 microchromosomes are recognizable (Ruiz, pers. comm.). It appears that a karyotype $12+20$, such as in several species of Liolaemus (Veloso, pers. comm.), is probably the rule in Vilcunia.

The present record of a new species of Vilcunia from tablelands south of the meseta of Lago Buenos Aires emphasizes the biogeographical interest of the genus. This finding underscores the herpetofaunal distinctiveness of the basaltic mesetas phytogeographically included in the SubAndean District (Cabrera, 1951). Although the Sub-Andean District is considered to be a single physiographic unit, our information increasingly supports its postulated partitioning (Cei, 1979), being recognizable as separate districts both the Humid Southern Lowlands and the isolated Western Volcanic Plateaus along the Patagonian mountains. A very harsh continental climate besets the several biotopes of the basaltic mesetas. Steppes, brachyblastic or rosulate vegetation, and lichen communities are involved in their predominant stunted associations. Often, as in the meseta of Lago Buenos Aires, true periglacial conditions prevail, close to the boundaries of Patagonian continental glaciers: they determine and restrict both adaptive trends and ecological relationships of the specialized ecosystems of the district. 
The rock-dwelling tropidurine Vilcunia is the most significant herpetofaunal element of this unusual biota. Liolaemus lineomaculatus and locally differentiated populations of the archeforus group, a southern stock of the genus Liolaemus, share in its habitat. We prefer not to attempt a tentative inference whether the strange Vilcunia may represent the survivors of a primitive and formerly more successful lineage of terrestrial iguanids, or whether they are a phyletically recent and specialized saxicolous genus, derived from some Liolaemus-like line adapted to the environmental conditions of basaltic ravines through glacial and postglacial times. Further comparative and ecological studies must be made on this exceptional iguanid group.

Acknowledgments.-We wish to thank $\mathrm{R}$. Negro and J. Stich for their outstanding assistance during our field work in the Lago Belgrano and Cerro Beltza region, and in the Aguila-Asador meseta. We are also indebted to O. Sala, Chairman of the Centro Nacional Patagónico of the Consejo Nacional Investigaciones Cientificas y Tecnicas, Puerto Madryn, Chubut, Argentina, for his constant interest and help in our herpetological research in southern Patagonia. We are especially grateful to E. Maury, Museo Argentino de Ciencias Naturales, Buenos Aires, and J. A. Ambrosetti, Instituto Argentino de Investigaciones Zonas Aridas, Mendosa, for their valuable cooperation in a prompt study of zoological and botanical samples from the explored area.

\section{Literature Cited}

Cabrera, A. L. 1951. Territorios fitogeográficos de la Republica Argentina. Bol. Soc. Argentina Bot. 4:21-65.

CEI, J. M. 1979. The Patagonian herpetofauna. In: The South American herpetofauna: its origin, evolution and dispersal. W. E. Duellman (ed.). Mus. Nat. Hist. Univ. Kansas Monogr. 7: 309-339.

Donoso Barros, R. 1966. Reptiles de Chile. Univ. Chile, Santiago. $458 \mathrm{pp}$.

Donoso Barros, R., AND J. M. Cei. 1971. New lizards from Patagonian volcanic tablelands of Argentina. J. Herpetol. 5:89-95.

ETHERIDGE, R. 1964. The skeletal morphology and systematic relationships of sceloporine lizards. Copeia 1964:610-631.

Paull, D., E. E. Williams, and W. P. Hall. 1976. Lizard karyotypes from the Galapagos Islands: chromosomes in phylogeny and evolution. Breviora (441):1-31.

Accepted: 15 March 1982. 